\title{
The effect of malnutrition on insulin binding to rat erythrocytes
}

\author{
BY HAZEL M. PAYNE-ROBINSON \\ Tropical Metabolism Research Unit, University of the West Indies, Kingston 7, Jamaica \\ AND RICHARD BROWN \\ Department of Medical Biochemistry, Welsh National School of Medicine, Cardiff
}

(Received 23 August 1990 - Accepted 8 May 1991)

\begin{abstract}
Insulin binding to erythrocyte receptors was compared in malnourished and control rats. Percentage specific insulin binding to malnourished rat erythrocytes was significantly lower than to control erythrocytes $(P<0.001)$. The low insulin binding in the malnourished rat erythrocytes was accompanied by low insulin receptor affinity $(P=0.035)$.
\end{abstract}

Malnutrition: Insulin binding: Erythrocytes: Rat

Abnormalities in cell membrane structure accompany many of the physiological changes characteristic of severe malnutrition. The evidence for abnormal structure and function has been obtained from studies with erythrocytes. In severely malnourished children, abnormalities in the lipid composition of erythrocyte membranes have been observed (Coward, 1971; Brown et al. 1978; Wolff et al. 1984; Vajreswari et al. 1990). Such alterations in membrane structure would be expected to affect membrane fluidity. Abnormal membrane fragility has also been observed (Ramanadham \& Kaplay, 1982). Abnormal function of the sodium pump has been shown in the erythrocytes of malnourished children (Patrick \& Golden, 1977; Narayanareddy \& Kaplay, 1982). The fluidity of the membrane affects the activities of the membrane-bound enzymes, and membrane $\mathrm{Na}^{+} / \mathrm{K}^{+}$-transporting ATPase (EC 3.6.1.37) activity (Kaplay, 1978), acetylcholinesterase (EC 3.1.1.7) activity (Kaplay, 1975) and $\mathrm{Ca}^{2+}, \mathrm{Mg}^{2+}$-adenosinetriphosphatase (EC 3.6.1.3) activity (Ramanadham \& Kaplay, 1982) have been shown to be altered in erythrocytes from kwashiorkor children. Another aspect of membrane function which may be disturbed by malnutrition is the ability of the receptors to bind insulin. Alterations of erythrocyte membrane structure which affect membrane fluidity have been shown to affect the properties of insulin receptors (Neufeld et al. 1986). The properties of erythrocyte insulin receptors have been studied in malnourished children and low-affinity binding has been found (Payne-Robinson et al. 1988).

The effect of nutrients on the erythrocyte insulin receptor has been extensively studied in adult human subjects, and dietary manipulations have been used to induce some of the changes observed (Spanheimer et al. 1982; Ward et al. 1984). However, although the effect of nutrient intake on insulin receptors in rat insulin target organs has been extensively studied (Ip et al. 1976; Sun et al. 1977; Grundleger \& Thenen, 1982), little is known of rat erythrocyte insulin receptors.

In the present study a convenient method was developed for the study of erythrocyte-insulin binding in a small-animal model, i.e the weanling malnourished rat. It was considered important to investigate whether the properties of erythrocyte insulin 
receptors in weanling malnourished rats were similar to those in weanling malnourished children, since an animal model lends itself to more comprehensive investigation of physiological abnormalities related to membrane function.

\section{MATERIALS AND METHODS}

\section{Animals}

Wistar rats were weaned to rat chow (Pillsbury rat diet $(\mathrm{g} / \mathrm{kg})$ : crude protein (nitrogen $\times 6 \cdot 25$ ) 169 , carbohydrate 486 , oil 26 , with added minerals and vitamins; metabolizable energy $13.5 \mathrm{~kJ} / \mathrm{kg}$ ). The rats had free access to drinking water. Five litters were required for the whole study. Each litter provided enough rats for two experiments. Four rats from each litter were used as controls, and the others (six to eight) were malnourished. The malnourished rats were individually housed. The control animals were offered the diet ad lib. The mean intake in the controls was $8-10 \mathrm{~g}$ rat chow $/ \mathrm{d}$, and the weight gain was $4-5 \mathrm{~g} / \mathrm{d}$. The other rats who were litter-mates of the controls were malnourished on a restricted diet which offered a daily ration of $3 \mathrm{~g}$ rat chow (average intake $2.6 \mathrm{~g}$ ), and which did not promote weight gain (Fig. 1). At 18.00 hours on the day before the experiment, the control and the malnourished rats were meal-fed $(75 \mathrm{mg}$ rat chow/g body-weight). The experiment was performed on the next day at 10.00 hours. Malnourished and control rats of the same age (between 15 and $25 \mathrm{~d}$ after weaning) were compared.

\section{Experimental procedure}

The insulin-binding experiment was conducted with blood pooled from different rats of the same litter. Approximately 3-4 $\mathrm{ml}$ heparinized blood was obtained from three or four malnourished rats, or from one or two control rats. Blood was collected into heparin by cardiac puncture from animals lightly anaesthetized with diethyl ether. The blood from each animal was collected in a separate tube, and immediately after collection the tubes were placed in crushed ice. After centrifugation $\left(600 \mathrm{~g}, 5 \mathrm{~min}\right.$ at $\left.4^{\circ}\right)$, the plasma was aspirated and pooled for storage at $-20^{\circ}$ for determination of insulin and glucose concentrations. The sedimented blood cells were then pooled and washed twice in $10 \mathrm{ml}$ HEPES-phosphate buffer ( $\mathrm{pH} \mathrm{8.2).} \mathrm{After} \mathrm{each} \mathrm{wash,} \mathrm{the} \mathrm{upper} 100 \mu \mathrm{l}$ of cells were discarded with the supernatant fraction to remove residual mononuclear cells and reticulocytes. Finally, $6 \mathrm{ml}$ HEPES-phosphate buffer with human serum albumin $(10 \mathrm{~g} / \mathrm{l})$ was added to the sedimented erythrocytes. The leucocyte:erythrocyte in this final suspension was less than 1:7000000.

\section{Insulin-binding experiment}

The method used was that of Gambhir et al. (1978). Approximately $6 \mathrm{ml}$ erythrocyte suspension was available for each competitive-binding curve and for determination of cell counts. Portions $(400 \mu \mathrm{l})$ of erythrocyte suspension $\left(1.5-2.5 \times 10^{9}\right.$ erythrocytes $\left./ \mathrm{ml}\right)$ in duplicate were added to a series of polypropylene microfuge tubes. Each tube contained $50 \mathrm{pg}{ }^{125} \mathrm{I}$-labelled A14-porcine insulin (specific activity $250-275 \mathrm{Ci} / \mathrm{g}$ ) in $50 \mu \mathrm{l}$ buffer and, with the exception of one duplicate set, $50 \mu \mathrm{l}$ of one of a series of solutions of unlabelled insulin (Sigma porcine, $25.5 \mathrm{U} / \mathrm{mg}$ ) in HEPES-phosphate buffer with albumin $(10 \mathrm{~g} / 1)$. The concentration range of the unlabelled insulin solutions was $1.67 \times 10^{-11} \mathrm{M}-1.67 \times 10^{-6} \mathrm{M}$. There were seven tubes in duplicate for each binding curve, including one duplicate set without unlabelled insulin. The cells were vortex mixed $(3 \mathrm{~s})$ and incubated at $15^{\circ}$ for $90 \mathrm{~min}$. Then $400 \mu \mathrm{l}$ of the incubated suspension were transferred to prechilled microfuge tubes containing $200 \mu \mathrm{l}$ dibutylphthalate, and immediately centrifuged 
in an Eppendorf microfuge for $30 \mathrm{~s}$. The supernatant fraction and dibutylphthalate were removed by suction. The microfuge tubes with sedimented erythrocytes were placed directly into counting tubes for determination of radioactivity in an autogamma counter. The percentage of radioactivity bound by $4 \times 10^{9}$ erythrocytes at an insulin concentration of $1.67 \times 10^{-6} \mathrm{M}$ was used to measure non-specific binding (range $1.5-2.5 \%$ of the total radioactivity added). The non-specific binding was subtracted from the percentage of total radioactivity bound in each tube to give the percentage of insulin specifically bound. The specific binding in the absence of unlabelled insulin was taken as the maximum specific insulin binding (SB). Iodinated insulin degradation in the incubation medium (tested by trichloroacetic acid precipitability) was $<10 \%$ of the total radioactivity, and did not differ between the malnourished and control experiments.

\section{Analytical methods}

Insulin was assayed by the double-antibody method of Hales \& Randle (1963) modified for increased sensitivity (Robinson \& Picou, 1977) using rat insulin standards (courtesy of Eli Lilly). Glucose was determined using glucose oxidase $(E C 1.1 .3 .4)$ and peroxidase (EC 1.11.1.7) (Huggett \& Nixon, 1957).

\section{Data analysis}

Insulin receptor binding to erythrocytes was quantitatively assessed as follows:

(1) Competitive binding curves in which the percentage of total radioactivity specifically bound was plotted as a function of insulin concentration;

(2) Scatchard analysis in which bound: free radioactive insulin was plotted as a function of bound hormone (Scatchard, 1949). This was a curvilinear plot, characteristic of insulin receptors (De Meyts \& Roth, 1975). The number of receptor sites and the affinity constant were calculated from the plot for insulin concentrations in the ranges (1) $1.67 \times 10^{-11}-1.67 \times 10^{-9} \mathrm{M}$ ), and (2) $1.67 \times 10^{-9}-1.67 \times 10^{-7} \mathrm{M}$ );

(3) the significance of the difference between means was calculated by unpaired $t$ test. To facilitate the use of parametric statistical analyses, the variables had to be transformed. Log transformations were used for specific insulin binding, receptor affinity and the numbers of receptor sites.

\section{RESULTS}

The change in body-weight $(\mathrm{g})$ from weaning to $30 \mathrm{~d}$ post weaning in malnourished and control rats are compared in Fig. 1. In the malnourished rats, body-weight declined slightly during the first $5 \mathrm{~d}$ after weaning and did not change significantly during the following $25 \mathrm{~d}$. In the control rats, body-weight increased slightly during the first $5 \mathrm{~d}$ after weaning, and then increased rapidly at the rate of $4-5 \mathrm{~g} / \mathrm{d}$. At $30 \mathrm{~d}$ post weaning, the control rats were still gaining weight at the same rate.

A comparison of the competitive-binding curves for erythrocytes from malnourished and control rats are shown in Fig. 2(a). The percentage specific insulin binding (SB) in the erythrocytes from the malnourished rats was significantly less than that in the control erythrocytes $(P<0.001)$. In the lower range of insulin concentrations (Fig. 2(a)) the low SB was accompanied by a low insulin receptor affinity in the malnourished rats compared with the control rats $(P<0.05)$, but no difference was shown in the number of receptor sites (Table 1). Affinity and sites in the higher range of insulin concentrations did not differ in the malnourished and control erythrocytes. Scatchard plots from which the affinity constants and the number of sites were calculated are shown in Fig. 2(b). A comparison of the affinity and the number of sites in the concentration ranges ( 1 and 2 ) of the Scatchard plot is shown in Fig. 3. 

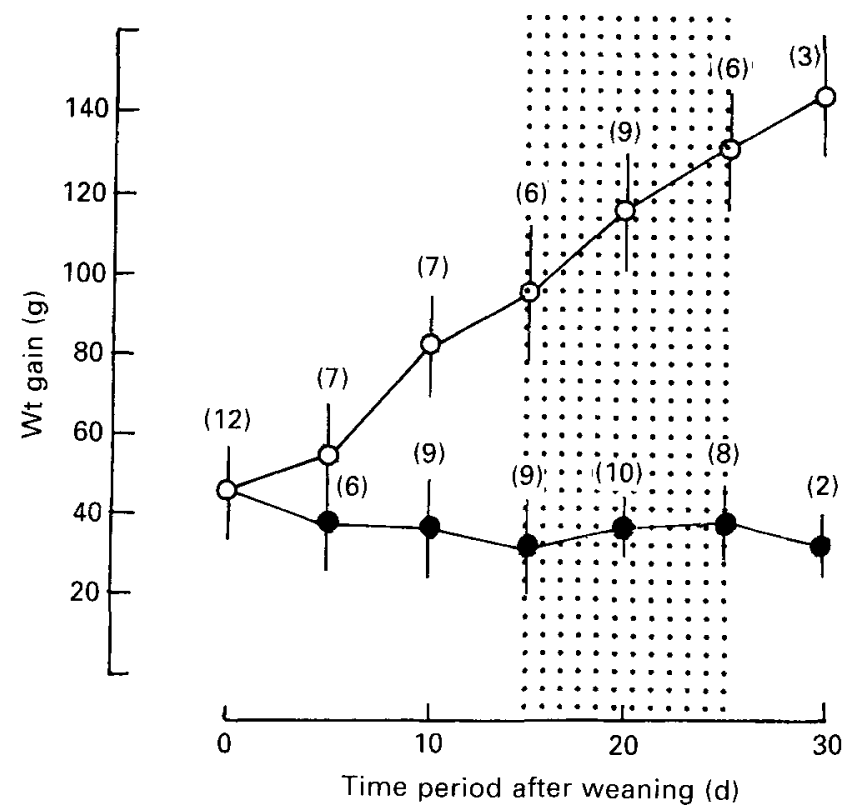

Fig. 1. Comparison of weight gain from the time of weaning $(21 \mathrm{~d})$ until $30 \mathrm{~d}$ after weaning in control $(O)$ and malnourished (O) rats. For details of dietary treatments, see p. 280 . $\mathrm{B}$, The period during which the experiments were done. Values are means and standard deviations represented by vertical bars for the nos. of animals weighed at each time-point shown in parentheses.

Fasting plasma insulin was approximately four times higher in the control rats than in the malnourished rats $(P<0.001)$, but there was no difference in fasting plasma glucose levels (Table 1).

\section{DISCUSSION}

Our results demonstrated that food restriction in weanling malnourished rats induced changes in the erythrocyte membrane which led to decreased insulin binding and receptor affinity. However, severe malnutrition is apparently a different physiological state from acute starvation in which the opposite effect has been shown. Acute food deprivation is known to induce increased insulin binding to its receptor, and this has been demonstrated in circulating cells (DeFronzo et al. 1978; Wachslicht-Rodbard et al. 1979).

Specific insulin binding was approximately $44 \%$ less in the malnourished rat erythrocyte than in the control. The decreased insulin binding was associated with a $40 \%$ decrease in receptor affinity, with no apparent decrease in the number of receptor sites. However, the method used in the present study did not allow accurate analysis of receptor concentration. Nevertheless the results are in agreement with those from studies in malnourished children in which low erythrocyte insulin receptor affinity was also found (Payne-Robinson et al. 1988). In the malnourished rat hepatocyte, low receptor affinity was also found, but this was associated with an increase in receptor concentration (Thakur et al. 1988). In healthy men with marginal energy deficiency, erythrocyte insulin binding was $16 \%$ decreased but receptor affinity was not altered (Garrel et al. 1984).

Whether the erythrocyte abnormalities in malnutrition are reflected in the typical insulin target cells is unknown. In some physiological conditions erythrocyte insulin receptors have similar binding properties to typical insulin target cells (Olevsky \& Reaven, 1977; De Pirro et al. 1980). However, there are problems in extrapolating from insulin binding in 

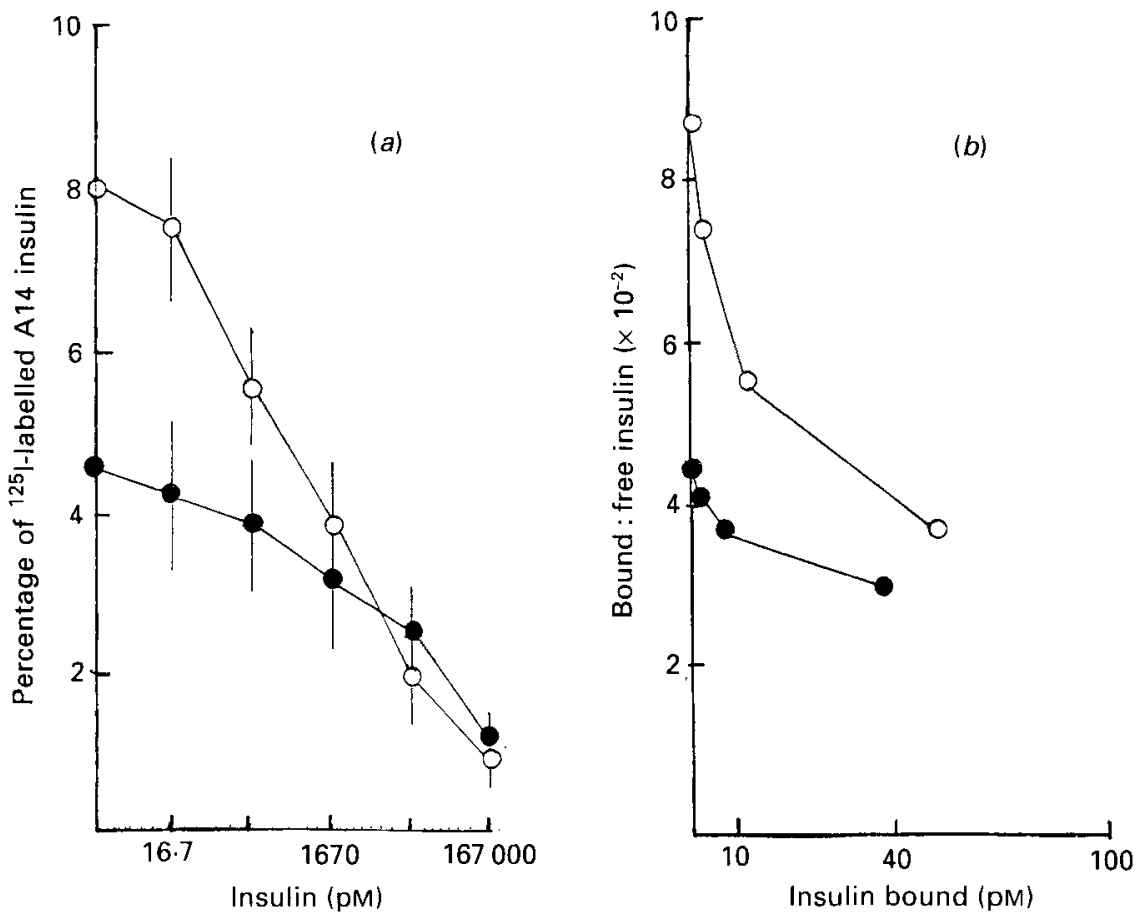

Fig. 2. (a) Comparison of the competitive binding curves of the percentage radioactivity bound by $4 \times 10^{9}$ erythrocytes in the presence of unlabelled insulin solutions in the concentration range $16.7-167000$ pM for malnourished $(-)$ and control $(O)$ rats. For details of dietary treatments, see p. 280. Points are means with their standard errors represented by vertical bars. $(b)$ Scatchard plots derived from the first four points of the binding curve. The insulin receptor affinity and the number of receptor sites were calculated from this plot (Table 1).

Table 1. Comparison of the properties of erythrocyte insulin receptors from malnourished and control rats

(Mean values and standard deviations)

\begin{tabular}{|c|c|c|c|c|c|}
\hline \multirow[t]{2}{*}{ No. of experiments... } & \multicolumn{2}{|c|}{$\begin{array}{c}\text { Malnourished } \\
10\end{array}$} & \multicolumn{2}{|c|}{$\begin{array}{c}\text { Control } \\
10\end{array}$} & \multirow{2}{*}{$\begin{array}{c}\text { Statistical } \\
\text { significance of } \\
\text { difference: } P\end{array}$} \\
\hline & Mean & SD & Mean & SD & \\
\hline Specific ${ }^{125}$ I-labelled A14 insulin bound (\%) & $4 \cdot 2$ & $3 \cdot 2$ & 7.6 & 2.9 & $<0.001$ \\
\hline Affinity constant ${ }^{*}\left(\times 10^{8} / \mathrm{M}\right)$ & $2 \cdot 5$ & 1.9 & $7 \cdot 0$ & $6 \cdot 1$ & $<0.035$ \\
\hline No. of receptor sites per cell* & 46 & 53 & 29 & 28 & \\
\hline Plasma insulin (pM) & $42 \cdot 2$ & $12 \cdot 7$ & $161 \cdot 3$ & $68 \cdot 5$ & $<0.001$ \\
\hline Plasma glucose (mM) & 3.9 & 0.56 & $3 \cdot 7$ & 1.56 & \\
\hline
\end{tabular}

* The affinity constants and the numbers of sites were calculated from Scatchard plots derived from the percentage radioactivity bound by $4 \times 10^{9}$ erythrocytes $/ \mathrm{ml}$ in the insulin concentration range $16.7-1670 \mathrm{pm}$.

erythrocytes to that in other tissues. For instance, there are differences in the mechanism by which the receptors of erythrocytes and monocytes are regulated (Dons et al. 1981), although they have the same structure (Ward \& Harrison, 1986). In addition, erythrocyte insulin binding is closely related to cell age (Kosmakos et al. 1980), and a preponderance 


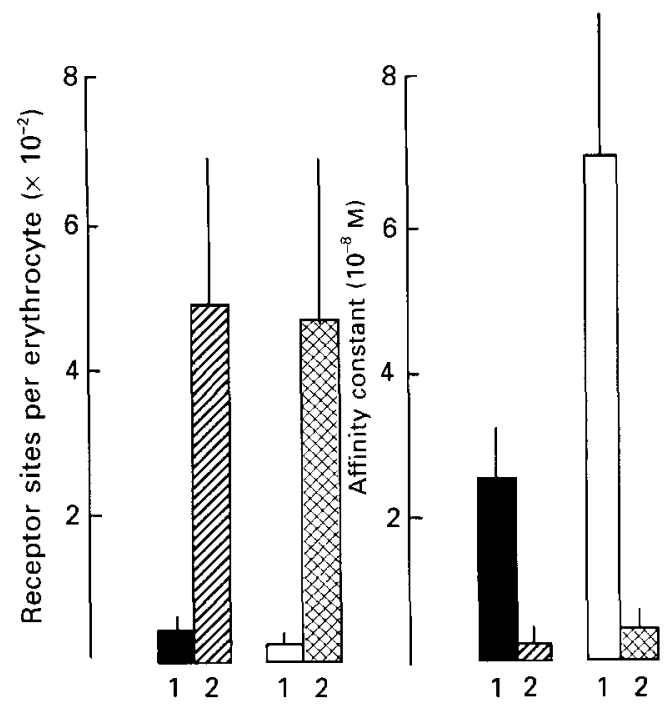

Fig. 3. Comparison of the number of sites and the receptor affinity in the high-affinity region (1) and the lowaffinity region (2) of the Scatchard plots in erythrocytes from malnourished $(\square, \Xi)$ and control $(\square, 8)$ rats. For details of dietary treatments, see p. 280.

of old erythrocytes and few newly synthesized erythrocytes were found in malnutrition suggesting that erythropoiesis is impaired (Ramdath et al. 1985).

There is impaired glucose tolerance, using either an oral or intravenous glucose load, in both children and experimental animals with severe malnutrition (Baig \& Edozien, 1965; James \& Coore, 1970; Weinkove et al. 1976), and insulin insensitivity has been demonstrated in vivo (Alleyne et al. 1972). Comparison of the erythrocyte and insulin target-cell receptors in malnutrition would help to resolve this problem.

Low fasting plasma insulin was found in the malnourished rats. This confirms the findings of others (Weinkove et al. 1976). However, in the present study there was no difference in the fasting plasma glucose in the malnourished and control rats.

In conclusion, the sensitivity of the rat erythrocyte to insulin was decreased during malnutrition. This may be related to the structural abnormality of the erythrocyte membrane characteristic of severe malnutrition. Whether the erythrocyte receptor faithfully mimics the receptor in typical insulin target tissues can only be ascertained by studies on such tissues. These studies may be conveniently carried out in an animal model such as the rat. Low insulin receptor binding or affinity, or both, may be related to the carbohydrate intolerance of malnutrition.

H.M.P.-R. gratefully acknowledges the facilities for this work while on study leave provided by Dr Stuart Woodhead, Department of Medical Biochemistry, Welsh National School of Medicine, and the kind hospitality of the staff at this institution. The authors wish to thank Dr D. T. Simeon for advice on statistical analysis.

This work was jointly supported by the British Council and the Welsh National School of Medicine.

\section{REFERENCES}

Alleyne, G., Trust, P., Flores, H.\& Robinson, H. (1972). Glucose tolerance and insulin sensitivity in malnourished children. British Journal of Nutrition 27, 585-592. 
Baig, H. A. \& Edozien, J. C. (1965). Carbohydrate metabolism in kwashiorkor. Lancet ii, 662-665.

Brown, K. H., Suskind, R. M., Lubin, B., Kulapongs, P., Leitzmann, C. \& Olsen, R. E. (1978). Changes in red blood cell membrane in protein calorie malnutrition. American Journal of Clinical Nutrition 31, 574-578.

Coward, W. A. (1971). The erythrocyte membrane in kwashiorkor. British Journal of Nutrition 25, 145-151.

De Fronzo, R. A., Soman, V., Sherwin, R. S., Hendler, R. \& Felig, P. (1978). Insulin binding to monocytes and insulin action in human obesity, starvation and refeeding. Journal of Clinical Investigation 62, 204-213.

De Meyts, P. \& Roth, J. (1975). Cooperativity in ligand binding: A new graphic analysis. Biochemistry and Biophysics Research Communications 66, 1118-1125.

De Pirro, R., Fusco, A., Lauro, R., Testa, I., Ferreti, F. \& De Martinis, C. (1980). Erythrocyte insulin receptors in non-insulin-dependent diabetes mellitus. Diabetes 29, 96-99.

Dons, R. F., Ryan, J., Gorden, P. \& Wachslicht-Rodbard, H. (1981). Erythrocyte and monocyte insulin binding in man. A comparative analysis in normal and disease states. Diabetes 30, 896-902.

Gambhir, K., Archer, J. \& Bradley, C. (1978). Characteristics of human erythrocyte insulin receptors. Diabetes 27, 701-708.

Garrel, D. R., Todd, K. S. \& Calloway, D. H. (1984). Effects of marginally negative energy balance on insulin binding to erythrocytes of normal men. American Journal of Clinical Nutrition 39, 716-721.

Grundleger, M. L. \& Thenen, S. W. (1982). Decreased insulin binding, glucose transport, and glucose metabolism in soleus muscle of rats fed a high fat diet. Diabetes 31, 232-237.

Hales, C. N. \& Randle, P. J. (1963). Immunoassay of insulin with insulin-antibody precipitate. Biochemical Journal 88, 137-146.

Huggett, A. S. \& Nixon, D. A. (1957). Use of glucose oxidase, peroxidase, and o-dianisidine in the determination of blood and urinary glucose. Lancet ii, $368-370$.

Ip, C., Tepperman, H. M., Holohan, P. \& Tepperman, J. (1976). Insulin binding and insulin response of adipocytes from rats adapted to fat feeding. Joumal of Lipid Research 17, 588-599.

James, W. P. T. \& Coore, H. G. (1970). Persistent impairment of insulin secretion and glucose tolerance after malnutrition. American Journal of Clinical Nutrition 23, 386-389.

Kaplay, S. S. (1975). Some modified properties of human erythrocyte acetyl cholinesterase in protein-calorie deficient subjects. Indian Journal of Biochemistry and Biophysics 12, 284-286.

Kaplay, S. S. (1978). Erythrocyte membrane $\mathrm{Na}^{+}$and $\mathrm{K}^{+}$activated adenosine triphosphate in protein-calorie malnutrition. American Journal of Clinical Nutrition 31, 579-584.

Kosmakos, F. C., Nagulsparan, M. \& Bennett, P. (1980). Insulin binding to erythrocytes: A negative correlation with red cell age. Journal of Clinical Endocrinology and Metabolism 51, 46-50.

Narayanareddy, K. \& Kaplay, S. S. (1982). $\left({ }^{3} \mathrm{H}\right)$ Ouabain binding to human erythrocytes in protein-energy malnutrition. Clinica Chimica Acta 122, 271-277.

Neufeld, N. D., Ezrin, C., Corbo, L., Long, D. \& Bush, M. A. (1986). Effects of caloric restriction and exercise on insulin receptors in obesity: Association with changes in membrane lipids. Metabolism 35, 580-587.

Olevsky, J. M. \& Reaven, G. M. (1977). Insulin binding in diabetes: Relationships with plasma insulin levels and insulin sensitivity. Diabetes 26, 680-686.

Patrick, J. \& Golden, M. H. N. (1977). Leucocyte electrolytes and sodium transport in protein energy malnutrition. American Journal of Clinical Nutrition 30, 1478 1481.

Payne-Robinson, H. M., Coore, H. G. \& Golden, M. H. N. (1988). Red cell insulin binding in Jamaican malnourished children. Clinical Research 36, 792A Abstr.

Ramanadham, M. \& Kaplay, S. S. (1982). Erythrocyte osmotic fragility in protein-energy malnutrition: cholesterol, phospholipid and $\mathrm{Ca}^{2+}, \mathrm{Mg}^{2+}$ adenosine triphosphatase. Biochemical Medicine 27, 226-231.

Ramdath, D., Golden, M. \& Bennett, F. (1985). Superoxide dismutase in red cell fractions in severe malnutrition. West Indian Medical Journal 34, Suppl., 46.

Robinson, H. M. \& Picou, D. (1977). A comparison of fasting plasma insulin and growth hormone concentrations in marasmic, kwashiorkor, marasmic-kwashiorkor, and underweight children. Pediatatric Research 11 , $637-640$

Scatchard, G. (1949). The attraction of proteins for small molecules and ions. Annals of the New York Academy of Sciences $\mathbf{5 1}, 660-672$.

Spanheimer, R. C., Bar, R. S., Ginsberg, B. H., Peacock, M. L. \& Martino, I. (1982). Comparison of insulin binding to cells of fed and fasted obese patients: Results in erythrocytes and monocytes. Journal of Clinical Endocrinology and Metabolism 54, 40-46.

Sun, J. V., Tepperman, H. M. \& Tepperman, J. (1977). A comparison of insulin binding by liver plasma membranes of rats fed a high glucose or a high fat diet. Journal of Lipid Research 18, 533-539.

Thakur, V. S., Thakur, V., Singh, O., Mittal, A., Karmakar, M. G. \& Ahuja, M. M. S. (1988). Protein calorie malnutrition: is the basic anomaly in insulin secretion or tissue receptors? Diabetologia 31, 403.

Vajreswari, A., Narayanareddy, K. \& Srinivasa Rao, P. (1990). Fatty acid composition of erythrocyte membrane lipid obtained from children suffering from kwashiorkor and marasmus. Metabolism 39, 779 - 782.

Wachslicht-Rodbard, H., Gross, H. A., Rodbard, D., Ebert, M. H. \& Roth, J. (1979). Increased insulin binding to erythrocytes in Anorexia nervosa. Restoration to normal with refeeding. New England Journal of Medicine 300, 882-887.

Ward, G. M. \& Harrison, L. C. (1986). Structure of the human erythrocyte insulin receptor. Diabetes 35, $101-105$. 
Ward, G. M., Naylor, B. A., Sargent, R. M. \& Turner, R. C. (1984). Abnormal dietary regulation of erythrocyte insulin receptor affinity in non-insulin dependent diabetes mellitus. Clinical Endocrinology 20, 671-682.

Weinkove, C., Weinkove, E. \& Pimstone, B. (1976). Glucose tolerance and insulin release in malnourished rats. Clinical Science and Molecular Medicine 50, 153-163.

Wolff, J. A., Margolis, S., Bujdoso-Wolff, K., Matusick, E. \& MacLean, W. C. Jr (1984). Plasma and red blood cell fatty acid composition in children with protein-calorie malnutrition. Pediatric Research 18, 162-167. 